\title{
ANALISIS ASPEK INPUT PADA UPAYA PROMOSI PEMBERIAN ASI EKSKLUSIF
}

\section{ANALYSIS OF INPUT ASPECTS PROMOTIONAL EFFORTS TO GIVE EXCLUSIVE BREASTFEEDING}

\author{
Tri Ari Prasetyowati $\left.{ }^{1)}\right)^{*}$, Ari Yuniastuti ${ }^{2) b}$, Oktia Woro Kasmini Handayani ${ }^{2) b}$ \\ 1) Akademi Kebidanan Duta Dharma Pati \\ a) Jl. Raya Pati-Kudus Km. 6 Margorejo Pati. 59163. Jawa Tengah \\ ${ }^{2)}$ Universitas Negeri Semarang \\ ${ }^{b)}$ Jl. Kelud Utara III Semarang 50237. Jawa Tengah \\ *Email : triariprasetyowati85@gmail.com
}

\begin{abstract}
The benefits of exclusive breastfeeding are in accordance with one of the goals of the Millennium Development Goals (MDGs), namely reducing child mortality and improving maternal health. The research objective is to analyze the implementation of input aspects of promotional efforts for exclusive breastfeeding including: 1) human resources (HR), 2) funding resources, 3) infrastructure, and 4) availability of Standard Operating Procedures (SOPs). This research uses qualitative approach which is focused on efforts to promote exclusive breastfeeding. The informants of the study were determined by purposive sampling and snowball sampling techniques. Data collection technique uses in-depth interview. The results of the study are: 1) midwives become official workers to promote exclusive breastfeeding, 2) the funding for exclusive breastfeeding promotion comes from the government, 3) the infrastructures to support exclusive breastfeeding are available sufficiently, and 4) standard operating procedures to support exclusive breastfeeding are not available yet. Finally, The Government is recommended to strengthen exclusive breastfeeding promotions by allocating special promotion workers in sufficient number, providing SOPs to promote exclusive breastfeeding.
\end{abstract}

Keywords: exclusive breastfeeding, human resource, promotional effort

\begin{abstract}
ABSTRAK
Manfaat pemberian air susu ibu (ASI) eksklusif sesuai dengan salah satu tujuan dari Millenium Development Goals (MDGs) yaitu mengurangi tingkat kematian anak dan meningkatkan kesehatan ibu. Tujuan penelitian untuk menganalisis implementasi aspek input upaya promosi pemberian ASI eksklusif yang meliputi: Sumber Daya Manusia (SDM), sumber dana, sarana prasarana, dan ketersediaan SOP. Penelitian ini menggunakan pendekatan kualitatif yang difokuskan pada upaya-upaya promosi pemberian ASI eksklusif. Informan penelitian ditentukan dengan teknik purposive sampling dan snowball sampling. Teknik pengambilan data dengan wawancara mendalam. Hasil penelitian menunjukkan: 1) sumber daya manusia yang melakukan promosi ASI eksklusif adalah bidan, 2) sumber dana promosi ASI eksklusif dari pemerintah berupa dana Bantuan Operasional Kesehatan (BOK), 3) ketersediaan sarana prasarana promosi ASI eksklusif sudah memadai, dan 4) belum tersedianya SOP promosi pemberian ASI eksklusif. Oleh karena itu Dinas Kesehatan perlu membuat SOP yang jelas untuk promosi pemberian ASI eksklusif bagi petugas promosi kesehatan. Puskesmas perlu melakukan upaya perekrutan tenaga khusus untuk promosi kesehatan.
\end{abstract}

Kata kunci: air susu ibu eksklusif, sumber daya manusia, upaya promosi 


\section{PENDAHULUAN}

Air Susu Ibu (ASI) eksklusif adalah air susu ibu yang diberikan kepada bayi sampai bayi berusia 6 bulan tanpa diberikan makanan dan minuman, kecuali obat dan vitamin (Ernawati, 2014). Kebijakan nasional untuk memberikan ASI eksklusif selama 6 (enam) bulan telah ditetapkan dalam SK Menteri Kesehatan No.450/Menkes/SK/IV/2004 (Dinas Kesehatan Kabupaten Pati, 2016). Pemerintah daerah disarankan untuk menyusun peraturan daerah yang mendukung pelaksanaan program inisiasi menyusu dini dan pemberian ASI eksklusif. Peraturan daerah memiliki kekuatan hukum mengikat bagi semua pihak yang terlibat dalam program ASI eksklusif. Program inisiasi menyusu dini dan ASI eksklusif meliputi promosi, pelaksanaan, pemantauan, pengawasan dan evaluasi terkait capaian program tersebut.

Dinas Kesehatan Kabupaten Pati terus berupaya meningkatkan kapasitas pelatihan konseling menyusui bagi petugas Puskesmas dan rumah sakit di wilayah Kabupaten Pati. Pelatihan tersebut bertujuan untuk mencapai tumbuh kembang bayi/anak yang optimal sekaligus mempertahankan kesehatan ibu setelah melahirkan. Tindak lanjut dari pelatihan tersebut, di setiap Perangkat Daerah diharuskan ada ruang laktasi atau tempat untuk menyusui di setiap instansi. Konselor yang ahli di dalam konseling menyusui harus ada di setiap instansi. Setelah mengikuti pelatihan, para konselor diharapkan dapat memberikan dan meningkatkan konselingnya (Dinas Kesehatan Kabupaten Pati, 2016).

Hasil Pemantauan Status Gizi (PSG) tahun 2016 menunjukkan persentase bayi di Indonesia yang mendapatkan ASI eksklusif sampai usia enam bulan sebesar $29,5 \%$. Pencapaian tersebut belum sesuai dengan target rencana strategis (Renstra) tahun 2016 secara nasional cakupan pemberian ASI eksklusif pada bayi $0-6$ bulan sebesar $42 \%$ (Kementerian Kesehatan RI, 2016). Persentase pemberian ASI eksklusif pada bayi 0-6 bulan di Provinsi Jawa Tengah pada tahun 2016 sebesar 54,2\%, menurun jika dibandingkan persentase pemberian ASI eksklusif tahun 2015 yaitu 61,6\% (Dinas Kesehatan Provinsi Jawa Tengah, 2017).
Cakupan pemberian ASI eksklusif di Kabupaten Pati tahun 2016 sebesar 74,2\%, meningkat dibandingkan tahun 2015 sebesar $72,1 \%$, tahun 2014 sebesar $71,53 \%$, tahun 2013 sebesar 64,8\%, serta tahun 2012 sebesar $62,45 \%$. Sementara itu, cakupan tertinggi terdapat di Puskesmas Tayu II sebesar 96,7\% dan cakupan terendah di Puskesmas Pati II sebesar 60,9\% (Dinas Kesehatan Kabupaten Pati, 2017).

Kesehatan anak balita merupakan salah satu indikator yang mencerminkan tingkat kesejahteraan masyarakat. Balita yang sehat merupakan aset penting dalam kelangsungan masa depan bangsa. Pola dan lama pemberian ASI memberikan pengaruh yang sangat positif pada kondisi kesehatan dan proses tumbuh kembang anak secara optimal. Enzim dalam ASI membantu pertumbuhan otak, pembentukan tulang serta mencegah penyakit dan infeksi pada bayi (Badan Pusat Statistik Kabupaten Pati, 2017). Berdasarkan uraian diatas, tujuan penelitian adalah untuk menganalisis aspek input upaya-upaya promosi pemberian ASI eksklusif di Wilayah Kerja Puskesmas Pati II.

\section{TINJAUAN PUSTAKA}

\section{ASI Eksklusif}

ASI merupakan makanan terbaik untuk bayi selama 2 tahun dan tidak ada makanan lain yang direkomendasikan selain ASI (Alimoradi, et al., 2014). Lebih lanjut, hasil penelitian Horton, et al. (2016) menyatakan bahwa promosi pemberian ASI merupakan salah satu tindakan yang paling efektif dalam rangka upaya pencegahan penyakit diare dan mencegah kematian yang dikarenakan oleh diare. Berdasarkan penelitian yang dilakukan oleh Rahmawati (2010), faktor-faktor yang mempengaruhi pemberian ASI eksklusif pada ibu menyusui antara lain dukungan petugas kesehatan. Ibu memperoleh penyuluhan dari tenaga kesehatan baik di tempat melahirkan maupun di tempat ANC (antenatal care). Tenaga kesehatan memberikan informasi tentang manfaat ASI eksklusif dan berbagai penyuluhan yang berkaitan dengan menyusui. Hal ini menimbulkan kepercayaan diri dari ibu untuk terus memberikan ASI eksklusif. 


\section{Manfaat ASI Eksklusif}

Manfaat ASI bagi bayi adalah memudahkan kerja pencernaan, mudah diserap oleh usus bayi serta mengurangi timbulnya gangguan pencernaan seperti diare atau sembelit. ASI mengandung zat-zat gizi yang dibutuhkan bagi pertumbuhan dan perkembangan bayi termasuk untuk kecerdasan bayi. Manfaat ASI menurut aspek kesehatan ibu yaitu membantu mempercepat pengembalian uterus ke bentuk semula dan mengurangi perdarahan post partum karena isapan bayi pada payudara akan merangsang kelenjar hipofise untuk mengeluarkan hormon oksitosin (Marmi, 2014).

Manfaat ASI bagi keluarga yaitu ASI tidak perlu dibeli sehingga dana yang seharusnya digunakan untuk membeli susu formula dapat digunakan untuk keperluan lain. Penghematan juga disebabkan karena bayi yang mendapat ASI lebih jarang sakit sehingga mengurangi biaya berobat. Manfaat ASI dari aspek psikologi adalah kebahagiaan keluarga bertambah karena kelahiran lebih jarang. Kondisi ini mendekatkan hubungan bayi dengan keluarga sehingga suasana kejiwaan ibu menjadi baik. Menyusui juga sangat praktis, karena dapat diberikan dimana saja dan kapan saja (Wulandari \& Handayani, 2011).

Manfaat ASI bagi negara yaitu ASI dapat dianggap sebagai kekayaan nasional. Jika semua ibu menyusui diperkirakan dapat menghemat devisa sebesar Rp8,6 milyar yang seharusnya dipakai untuk membeli susu formula. ASI mengurangi subsidi untuk rumah sakit karena rawat gabung akan memperpendek lama rawat ibu dan bayi, mengurangi komplikasi persalinan dan infeksi nosokomial serta mengurangi biaya yang diperlukan untuk perawatan anak sakit. Anak yang mendapat ASI, lebih jarang dirawat di rumah sakit dibanding anak yang mendapat susu formula. Anak yang mendapat ASI dapat tumbuh kembang secara optimal, oleh karenanya kualitas generasi penerus bangsa akan terjamin (Walyani \& Purwoastuti, 2015).

\section{Upaya Promosi ASI Eksklusif}

Keputusan Menteri Kesehatan No. 1193/ Menkes/SK/X/2004 tentang Kebijakan Nasional Promosi Kesehatan dan Keputusan Menteri Kesehatan No.1114/Menkes/SK/
VII/2005 tentang Pedoman Pelaksanaan Promosi Kesehatan di daerah menyebutkan strategi dasar utama promosi kesehatan adalah (1) pemberdayaan, yang didukung oleh (2) bina suasana, dan (3) advokasi, serta dijiwai semangat (4) kemitraan (Hartono, 2010).

Oleh karena itu, perlu dilakukan suatu program yang dilaksanakan secara terarah dan terus-menerus dalam rangka peningkatan derajat kesehatan ibu dan bayi serta peningkatan cakupan ASI eksklusif. Menanamkan prinsip ASI eksklusif pada setiap asuhan yang diberikan bidan kepada masyarakat merupakan hal yang penting. Hal tersebut berhubungan dengan upaya untuk merubah perilaku bidan supaya selalu melakukan IMD (Inisiasi Menyusu Dini) dalam setiap pertolongan persalinan dan mendukung pemberian ASI eksklusif (Santi, 2017). Penelitian oleh Fikawati \& Syafiq (2009) menyimpulkan bahwa bidan seharusnya dapat mengawal pelaksanaan ASI eksklusif melalui pemberian nasihat, pemantauan, dan tindakan yang mendukung pelaksanaan ASI eksklusif. Masa ANC adalah saat yang paling tepat bagi tenaga kesehatan untuk memberitahu ibu berkaitan dengan persiapan menyusui dan pentingnya ASI eksklusif.

Upaya penyadaran tentang program ASI eksklusif kepada bidan merupakan tantangan yang sulit, namun bukan berarti tidak dapat dilaksanakan. Upaya tersebut membutuhkan metode yang tepat untuk menyampaikan informasi. Selain itu, perlu dilakukan evaluasi terhadap upaya yang telah dilakukan. Upaya yang dapat dilakukan adalah dengan melakukan promosi ASI eksklusif kepada bidan secara terencana dan ada evaluasinya. Promosi kegiatan dapat dilakukan dalam pola dan bentuk kegiatan, seperti: seminar, workshop, talkshow, simulasi ataupun penyebaran buku, leaflet, brosur, CD dan sebaran lainnya. Tergantung pada khalayak sasaran dan jenis pesan atau informasi yang ingin disebarluaskan (Lokra, 2018).

Promosi dapat dilakukan melalui tiga metode. Metode pertama adalah komunikasi tatap muka seperti pertemuan warga (musyawarah desa, musyawarah dusun), kunjungan rumah, kunjungan ke tempat-tempat berkumpulnya warga, lokakarya, dan rapat evaluasi. Metode promosi kedua adalah komunikasi massa seperti penyebarluasan leaflet, pamflet, poster, komik, newsletter, dan 
pemutaran film dokumenter. Adapun metode promosi ketiga adalah pelatihan pelaku seperti pelatihan untuk fasilitator, konselor maupun motivator ASI (Notoadmodjo, 2010).

Kasus gizi buruk yang terjadi hampir di seluruh wilayah Indonesia sebagian besar diderita oleh bayi berumur 6 bulan ke atas. Hal tersebut sebagai akibat pemberian ASI dan Makanan Pendamping Air Susu Ibu (MPASI) yang tidak tepat. Organisasi kesehatan dunia telah melakukan berbagai upaya untuk mempromosikan ASI. Petugas kesehatan dapat membantu memberikan konseling kepada ibuibu yang mengalami kesukaran dalam menyusui dan memberikan dukungan untuk memberikan dan meningkatkan ASI.

Bidan mempunyai peranan yang sangat penting dalam menyukseskan program tersebut. Sosialisasi sangat berpengaruh terhadap keberhasilan suatu program (Aprilia, 2010). Hasil penelitian Clark \& Bungun (2003) menyatakan bahwa tenaga kesehatan harus memberikan pendidikan kesehatan tentang manfaat menyusui ASI untuk meningkatkan angka cakupan menyusui.

\section{METODE PENELITIAN}

Jenis penelitian adalah kualitatif yang difokuskan pada upaya-upaya promosi pemberian ASI eksklusif. Pemilihan desain studi kualitatif dikarenakan hasil penelitian tidak untuk digeneralisasikan, dan data yang akan dihasilkan hanya berupa data kualitatif yang didukung data kuantitatif.

Penelitian dilakukan pada bulan Agustus -September 2018 di wilayah kerja Puskesmas Pati II. Pengumpulan data menggunakan wawancara mendalam (indepth interview), studi dokumentasi, dan pengisian kuesioner. Uji validitas data menggunakan teknik triangulasi. Data penelitian berupa data kualitatif yang berisi narasi dan dilengkapi dengan datadata kuantitatif. Terdapat dua jenis data dalam penelitian, yaitu data primer adalah data input yang terdiri kecukupan SDM, sumber dana, sarana prasarana, ketersediaan SOP, dan data sekunder adalah laporan tertulis dari bidan desa, data cakupan ASI eksklusif di Puskesmas Pati II, dan laporan tentang pelaksanaan promosi pemberian ASI eksklusif di wilayah kerja Puskesmas Pati II.
Sampel penelitian menggunakan tenik purposive sampling dengan 5 informan awal dan dikembangkan dengan teknik snowball sampling menjadi 13 informan. Informan terdiri dari Kepala Puskesmas, bidan koordinator, promotor kesehatan, petugas gizi, bidan desa 2 orang, ibu menyusui 3 orang (menyusui maksimal 6 bulan yang lalu), Kepala Seksi (Kasi) Kesehatan Keluarga, Kasi Promosi dan Pemberdayaan Masyarakat, dan kader kesehatan 2 orang. Analisis terhadap jawaban informan dilakukan pada saat wawancara. Aktivitas dalam analisis data kualitatif meliputi data reduction (reduksi data) dan data display (penyajian data).

\section{HASIL DAN PEMBAHASAN}

\section{Gambaran Karakteristik Informan}

Informan utama terdiri dari 6 tenaga kesehatan yang bertugas di Puskesmas Pati II Kabupaten Pati. Puskesmas Pati II terletak di Jl. Raya Pati-Tayu KM 04 Desa Ngepungrojo Kecamatan Pati Kabupaten Pati. Puskesmas Pati II merupakan bagian dari Wilayah Kecamatan Pati. Karakteristik informan utama tenaga kesehatan dijelaskan dalam Tabel 1.

Tabel 1.

Karakteristik Informan Utama Tenaga Kesehatan

\begin{tabular}{lrll}
\hline No & Kode & \multicolumn{1}{c}{ Pendidikan } & \multicolumn{1}{c}{ Jabatan } \\
\hline 1 & IU.1 & S1, Kedokteran & Kepala Puskesmas \\
2 & IU.2 & D3, Kebidanan & Bidan Koordinator \\
3 & IU.3 & D3, Kebidanan & Promotor Kesehatan \\
4 & IU.4 & D3, Gizi & Petugas Gizi \\
5 & IU.5 & D3, Kebidanan & Bidan Desa \\
6 & IU.6 & D3, Kebidanan & Bidan Desa \\
\hline
\end{tabular}

Karakteristik informan triangulasi terdiri dari pejabat struktural di Dinas Kesehatan Kabupaten Pati dan kader kesehatan di wilayah Puskesmas Pati II. Pejabat sruktural yang menjadi informan triangulasi adalah pejabat yang tugas pokok dan fungsinya berkaitan dengan program promosi ASI eksklusif. Adapun kader kesehatan menjadi informan triangulasi karena kader kesehatan langsung behubungan dengan masyarakat yang melaksanakan program pemberian ASI eksklusif. Karakter informan triangulasi disajikan dalam Tabel 2. 
Tabel 2.

Karakteristik Informan Triangulasi

\begin{tabular}{|c|c|c|c|}
\hline No & $\begin{array}{c}\text { Kode } \\
\text { Informan }\end{array}$ & Pendidikan & Jabatan \\
\hline 1 & IT.1 & $\begin{array}{l}\text { S2, } \\
\text { Magister } \\
\text { Manajemen }\end{array}$ & Kasi Kesga \\
\hline 2 & IT. 2 & $\begin{array}{l}\text { S2, } \\
\text { Magister } \\
\text { Kesehatan }\end{array}$ & $\begin{array}{l}\text { Kasi Promosi } \\
\text { dan } \\
\text { Pemberdayaan } \\
\text { Masyarakat }\end{array}$ \\
\hline 3 & IT. 3 & SMA & $\begin{array}{l}\text { Kader } \\
\text { kesehatan }\end{array}$ \\
\hline 4 & IT. 4 & SMA & $\begin{array}{l}\text { Kader } \\
\text { kesehatan }\end{array}$ \\
\hline
\end{tabular}

Aspek Input Promosi Pemberian ASI Eksklusif

Aspek input promosi pemberian ASI eksklusif di Wilayah Kerja Puskesmas Pati II meliputi sumber daya manusia (jumlah, tingkat pendidikan, dan pelatihan yang pernah dilakukan), sumber dana, sarana prasarana, dan ketersedian SOP.

\section{Sumber Daya Manusia}

Puskesmas Pati II belum memiliki tenaga khusus promosi kesehatan. Kepala Puskesmas Pati II dan staf penanggung jawab program promosi kesehatan Puskesmas Pati II mengatakan bahwa belum tersedia tenaga penyuluh kesehatan masyarakat dengan pendidikan minimal DIII kesehatan di bidang promosi kesehatan. Tenaga penyuluh/ promotor kesehatan yang ada di Puskesmas Pati II adalah seorang lulusan sekolah DIII Kebidanan.

Ketersediaan Sumber Daya Manusia (SDM) di Wilayah Puskesmas Pati II ditunjukkan oleh hasil wawancara terhadap informan utama sebagai berikut :

"....yang pegang program promosi kesehatan adalah bidan DIII,...ketersediaan bidan cukup, satu desa satu bidan desa, jumlah bidan ada 21, bidan desa ada 12 dan yang lain adalah bidan Puskesmas." (IU.1)

Pernyataan informan utama tersebut juga didukung oleh pernyataan dari informan triangulasi sebagai berikut:

"Pati II bidan yang ditugasi di Promkes... wilayah kami satu desa mempunyai satu bidan desa." (IT.1)
Pendidikan bidan desa di wilayah kerja Puskesmas Pati II adalah D1 Kebidanan sebanyak 3 orang dan yang berpendidikan DIII Kebidanan sebanyak 18 orang. Bidan koordinator Puskesmas berpendidikan DIII Kebidanan dan pada saat pelaksanaan penelitian sedang studi lanjut DIV Kebidanan. Bidan Puskesmas dan bidan desa hampir semuanya berpendidikan DIII Kebidanan, karena 3 orang bidan yang masih DI Kebidanan ada yang sedang melakukan studi lanjut DIV Kebidanan.

Hal ini sesuai yang diungkapkan oleh informan utama sebagai berikut :

“...bidan koordinatornya dan 1 orang bidan Puskesmas sedang proses studi lanjut DIV." (IU.1)

"Pendidikan bidan ada yang masih DI tapi sudah dianjurkan untuk kuliah DIII yaitu sejumlah 3 bidan." (IU.2)

Kemampuan seseorang tidak hanya berdasarkan latar belakang pendidikan saja, tetapi juga dapat dilihat dari jenis pelatihan yang pernah diikuti. Puskesmas Pati II mengikuti pelatihan-pelatihan tentang ASI eksklusif dengan mengirimkan perwakilan bidan yang kemudian dilakukan transfer knowledge dan skill kepada semua bidan di wilayah kerja Puskesmas Pati II. Pelatihan yang pernah diikuti adalah pelatihan sebagai fasilitator ASI eksklusif dan pelatihan kelas ibu hamil dan kelas ibu balita.

Hal ini sesuai yang diungkapkan oleh informan utama sebagai berikut:

"Bidan mengikuti pelatihan fasilitator ASI eksklusif dan pelatihan kelas ibu hamil dan kelas ibu balita." (IU.1)

Pernyataan informan utama tersebut juga didukung oleh penyataan dari informan triangulasi sebagai berikut:

"Upaya DKK dengan memberikan pelatihan kepada tenaga kesehatan terkait yaitu petugas gizi, bidan koordinator, dan kader. Pelatihan yang dilakukan DKK : pelatihan konselor bagi staf gizi, petugas gizi Puskesmas dan bidan koordinator, pelatihan motivator ASI bagi kader, pelatihan PMBA bagi petugas gizi dan beberapa bidan koordinator, pelatihan PMBA bagi Kader." (IT.1) 
"Saya pernah ikut kegiatan penyuluhan ASI di Puskesmas bersama dengan kaderkader." (IT.3 dan IT.4)

Hasil penelitian Sari \& Sulistyowati (2015) menyebutkan bahwa pendukung promosi kesehatan yang utama adalah sumber daya manusia. Sesuai dengan Surat Keputusan Menteri Kesehatan Nomor 1114/Menkes/SK/ VII/2005 menyebutkan bahwa standar tenaga khusus promosi kesehatan puskesmas adalah DIII Kesehatan dengan minat dan bakat di bidang promosi kesehatan. Berdasarkan pedoman promosi kesehatan Puskesmas memang tidak dilarang menugaskan seorang bidan atau tenaga kesehatan lain memegang program promosi kesehatan apabila tidak terdapat tenaga khusus. Namun demikian, tidak semua tenaga kesehatan bisa serta merta memegang program promosi kesehatan. Tenaga kesehatan yang bukan tenaga khusus promosi kesehatan harus memiliki kemampuan berupa pengetahuan dan keterampilan dalam menyampaikan informasi atau konseling.

Seorang bidan pasti selalu berkaitan erat dengan masalah ASI. Hal ini sesuai dengan hasil penelitian Raharjo (2014) yang menyebutkan bahwa peran bidan secara signifikan berpengaruh terhadap praktik ASI eksklusif. Puskesmas Pati II memberdayakan bidan Puskesmas dan bidan desa sebagai SDM dalam melakukan promosi pemberian ASI eksklusif. Setiap desa sudah terdistribusi satu orang bidan desa di masing-masing desa. Terdapat 12 bidan desa di wilayah kerja Puskesmas Pati II yang tersebar di 12 desa.

Menurut Prasetyono (2012) bahwa para bidan juga turut berperan menggalakkan ASI eksklusif. Hal itu sesuai dengan peran dan wewenang bidan, yang mengacu pada Keputusan Menteri Kesehatan Republik Indonesia Nomor 900/MenKes/SK/VII/2002 tentang Registrasi dan Praktik Bidan. Keputusan tersebut mengharapkan semua bidan yang memberikan pelayanan kesehatan kepada masyarakat, khususnya ibu hamil, melahirkan dan menyusui senantiasa berupaya memberikan penyuluhan mengenai pemberian ASI eksklusif sejak pemeriksaan kehamilan.

Bidan di wilayah kerja Puskesmas Pati II cukup berkualitas, meskipun masih ada 3 orang bidan yang dalam proses studi lanjut
DIII Kebidanan. Bidan di wilayah kerja Puskesmas Pati II juga berpengalaman, dan sudah pernah mengikuti pelatihan motivator ASI eksklusif. Kualitas sumber daya manusia sangat menentukan keberhasilan suatu program, terutama program promosi ASI eksklusif. Pengetahuan yang dimiliki petugas promosi kesehatan mempengaruhi pelaksanan promosi kesehatan di Puskesmas (Suryani, 2009).

Pendidikan semua bidan, baik bidan Puskesmas, bidan koordinator, maupun bidan desa di wilayah kerja Pukesmas Pati II adalah 3 orang DI Kebidanan dalam proses studi lanjut DIII Kebidanan, 2 orang DIII Kebidanan dalam proses studi lanjut DIV Kebidanan dan 16 orang berpendidikan DIII Kebidanan. Hal ini belum sesuai dengan Undang-Undang Nomor 36 tahun 2014 tentang Tenaga Kesehatan, pada pasal 9 ayat 1 menyebutkan bahwa tenaga kesehatan harus memiliki kualifikasi minimum Diploma Tiga.

Pendidikan Kepala Seksi Kesehatan Keluarga (Kesga) Dinas Kesehatan Kabupaten Pati adalah magister manajemen. Adapun Kepala Seksi Promosi dan Pemberdayaan Kesehatan masing-masing berpendidikan magister kesehatan. Kepala Puskesmas Pati II memiliki pendidikan sarjana kedokteran. Pendidikan Kasi Kesga DKK dan Kepala Puskesmas Pati II sebagai penanggung jawab pelayanan kesehatan maternal, sudah sesuai dengan Permenkes RI Nomor 971/MenKes/ Per/XI/2009 tentang Standar Kompetensi Pejabat Struktural Kesehatan, yaitu pendidikan Kepala Seksi dan Kepala Puskesmas adalah berlatar belakang pendidikan paling sedikit sarjana kesehatan.

Pengembangan sumber daya manusia meliputi kegiatan pendidikan, penelitian, dan pertemuan untuk meningkatkan wawasan, kemauan, dan keterampilan petugas kesehatan maupun kelompok-kelompok potensi masyarakat. Semua tenaga kerja yang ada di Puskesmas hendaknya memiliki pengetahuan dan keterampilan dalam memberi informasi atau konseling. Jika keterampilan tersebut ternyata belum dimiliki, maka seharusnya diselenggarakan program pelatihan/kursus (Departemen Kesehatan RI, 2007). Pelatihan adalah bagian dari pendidikan yang menyangkut proses belajar untuk memperoleh 
dan meningkatkan keterampilan di luar sistem pendidikan yang berlaku dalam waktu yangsingkat dengan metode yang lebih mengutamakan praktik (Notoatmodjo, 2007).

Upaya peningkatan SDM diberikan melalui pelatihan. Berdasarkan hasil wawancara dengan Kasi Promosi dan Pemberdayaan Kesehatan bahwa pelatihan yang dilakukan oleh DKK terkait upaya promosi ASI eksklusif antara lain, pelatihan konselor bagi staf gizi, petugas gizi Puskesmas dan bidan koordinator, pelatihan motivator ASI bagi kader, pelatihan PMBA (Pemberian Makan Bayi dan Anak) bagi petugas gizi dan beberapa bidan koordinator, pelatihan PMBA (Pemberian Makan Bayi dan Anak) bagi kader. Hal ini sesuai dengan hasil penelitian Budiono, et al. (2018) menyatakan bahwa selain bidan, yang menjadi motivator ASI adalah kader kesehatan yang biasa menangani Posyandu.

Pelatihan yang diberikan kepada kader mempunyai hubungan dengan kinerja kader (Wirapuspita, 2013). Penelitian Hasanah \& Suhat (2014) menyatakan bahwa kader Posyandu dapat ditingkatkan pengetahuannya dengan melakukan pembinan dan refreshing secara berkesinambungan setiap 6 bulan sekali. Pengetahuan KIA (Kesehatan Ibu dan Anak) yang baik oleh kader akan mendukung peran kader dalam pengunaan buku KIA sebagai edukasi kepada ibu (Sistiarani, dkk., 2013).

Pengalaman seorang pegawai dapat dilihat melalui lama kerja. Lama kerja menunjukkan lamanya seseorang melakukan pekerjaan yang menjadi tanggung jawabnya. Menurut Gibson (2009), pengalaman kerja seorang petugas kesehatan akan berpengaruh dalam mencapai keberhasilan suatu program. Lama kerja informan antara 5 tahun sampai 20 tahun. Hal tersebut menunjukkan bahwa pengalaman yang dimiliki oleh informan dalam memberikan promosi ASI eksklusif sudah lama. Menurut Yunita, dkk. (2013) bahwa seseorang yang berpengalaman dipandang lebih mampu melaksanakan tugas, dan semakin lama bekerja maka kecakapan seseorang lebih baik dan sudah dapat menyesuaikan dengan lingkungan kerja. Lama kerja bidan koordinator adalah 20 tahun. Hal ini sudah sesuai dengan kualifikasi bidan koordinator yaitu memiliki masa kerja klinis profesi minimal 5 tahun (Lingga, 2016).

Hasil penelitian Cauntiho, et al. (2005) menyebutkan promosi pemberian ASI eksklusif dapat juga dilakukan dengan memberikan pelatihan kepada tenaga kesehatan di rumah sakit berupa pelatihan Baby Friendly Hospital Initiative (BFHI) dan kunjungan rumah pada masa nifas. Hasil penelitian Rosita (2016) menyebutkan bahwa salah satu faktor yang paling dominan yang mempengaruhi pemberian ASI eksklusif yaitu penyuluhan tentang ASI eksklusif. Dukungan informasi bagi ibu hamil dan menyusui dalam memberikan ASI eksklusif dapat diperoleh dari berbagai pihak, yaitu dari orang-orang yang berpengaruh (significant others), tenaga kesehatan, pelayanan kesehatan, serta kemudahan dan kelengkapan akses informasi ASI eksklusif (Wibowo, 2016).

Upaya promosi pemberian ASI eksklusif harus dilakukan oleh semua pihak yang berhubungan dengan ibu hamil, ibu bersalin, dan ibu menyusui baik secara langsung maupun tidak langsung. Pihak yang berhubungan langsung dengan ibu adalah tenaga kesehatan yaitu bidan Puskesmas maupun bidan desa dan kader kesehatan. Pihak yang berhubungan tidak langsung dengan ibu adalah pemerintah yang dalam hal ini diperankan oleh pemerintah daerah melalui Dinas Kesehatan Kabupaten dan Puskesmas. Upaya promosi pemberian ASI eksklusif secara tepat dapat dilakukan oleh sumber daya manusia yang sesuai dengan bidang keahliannya yaitu bidan atau dapat dilakukan selain bidan dengan ketentuan telah memiliki pengetahuan dan keterampilan yang cukup tentang ASI eksklusif.

Bidan merupakan sumber daya manusia yang tepat sebagai pelaksana upaya promosi pemberian ASI eksklusif karena bidan merupakan individu yang mendampingi ibu dari sejak masa kehamilan. Hal ini sesuai dengan penelitian yang dilakukan oleh Ernawati (2014) yang menunjukkan ibu hamil mendapat informasi tentang ASI eksklusif ketika periksa kehamilan pada bidan. 
Bidan perlu diberi motivasi melalui pelatihan ASI eksklusif sehingga dapat meningkatkan kualitas pelayanan kesehatan terutama tentang pemberian ASI eksklusif. Kurangnya keterampilan dan pelatihan sering menjadi penghalang upaya promosi pemberian ASI eksklusif.

\section{Sumber Dana}

Sumber dana untuk promosi pemberian ASI eksklusif di Wilayah Kerja Puskesmas Pati II didapatkan dari Bantuan Operasional Kesehatan (BOK). Dana BOK digunakan untuk kegiatan promosi ASI esklusif di kelas ibu hamil sebagai pengganti biaya konsumsi. Ibu hamil yang datang di kelas ibu hamil tidak mendapatkan pengganti transportasi. Dana BOK diambilkan dari anggaran APBD I atau APBN. Hal ini sesuai yang diungkapkan oleh informan utama sebagai berikut:

"Promosi ASI eksklusif dilakukan di kelas ibu hamil, dana dari BOK." (IU.1)

"Pembiayaan anggaran dan kebutuhan logistik kegiatan promosi bersumber dari APBD I maupun APBD II." (IU.3)

Pernyataan informan utama tersebut juga didukung oleh penyataan dari informan triangulasi sebagai berikut:

"Sumber dana upaya promosi pemberian ASI eksklusif dari APBD II dan APBD provinsi." (IT.1)

"Tidak ada alokasi khusus untuk promosi ASI eksklusif di seksi promosi dan pemberdayaan kesehatan, kalau cetak folder diambilkan dari anggaran APBN Kabupaten Pati." (IT.2)

Dana merupakan hal yang sangat penting untuk menjalankan suatu program. Kegunaan dana sebagai penunjang kegiatan sesuai dengan pernyataan bahwa jika dana kurang, maka motivasi kerja staf akan turun, akhirnya akan mempengaruhi kinerja staf, sehingga target dan tujuan program tidak akan tercapai.

Anggaran promosi kesehatan merupakan pendukung promosi kesehatan. Fungsi utama Puskesmas seperti yang tertuang dalam Permenkes No. 75 Tahun 2014 bahwa Puskesmas berfungsi menyelenggarakan pelayanan kesehatan yang mengutamakan upaya promotif dan preventif. Alokasi anggaran yang rendah untuk pelaksanaan program promosi ASI eksklusif akan menghambat pelaksanaan program secara optimal. Mugeni, dkk. (2012) dalam jurnalnya menjelaskan bahwa anggaran kesehatan selama ini lebih mengutamakan pelayanan kuratif. Apabila alokasi anggaran promosi kesehatan kurang, maka akan menghambat penyelenggaraan upaya promotif dan preventif, yang pada akhirnya berakibat pada belum membaiknya derajat kesehatan Indonesia.

Puskesmas Pati II memperoleh dana yang digunakan untuk promosi pemberian ASI eksklusif berasal dari Pemerintah Kabupaten Pati dalam bentuk dana Bantuan Operasional Kesehatan (BOK) yang diteruskan ke Puskesmas untuk melakukan promosi. Sumber dana kegiatan promosi pemberian ASI eksklusif bersumber dari Bantuan Operasional Kesehatan (BOK) yaitu dana APBN. Dana BOK dipakai untuk pengeluaran belanja makan dan minum peserta kelas ibu hamil dan kelas ibu balita. Peserta kelas ibu hamil tidak mendapatkan uang pengganti transportasi karena tidak ada alokasi dana tersebut dalam anggaran BOK.

Promosi pemberian ASI eksklusif yang dilakukan melalui kegiatan ANC di puskesmas tidak membutuhkan alokasi dana khusus. Promosi pemberian ASI eksklusif yang dilakukan melalui kegiatan ANC di Posyandu, biasanya menggunakan dana dari iuran kas RT atau RW untuk pengeluaran belanja konsumsi. Adapun anggaran sarana dan prasarana untuk promosi pemberian ASI eksklusif mempunyai alokasi tersendiri dan tidak diambilkan dari dana BOK.

Upaya promosi pemberian ASI eksklusif memerlukan alokasi dana tambahan untuk menunjang dana yang telah disediakan oleh pemerintah. Upaya promosi tidak hanya dilakukan oleh satu pihak saja yaitu pemerintah, namun masyarakat juga harus berpartisipasi. Pemerintah telah memfasilitasi dana sebagai anggaran kegiatan upaya promosi pemberian ASI eksklusif, namun masyarakat juga bisa ikut berpartisipasi dengan mengkoordinir iuran kas RT maupun RW. Anggaran dari pemerintah digunakan sebagai anggaran sarana prasarana, media promosi, dan konsumsi peserta kelas ibu hamil dan kelas ibu balita dalam kegiatan upaya promosi pemberian ASI eksklusif. 
Dana yang berasal dari masyarakat bisa dikelola oleh masyarakat sendiri atau oleh bidan desa. Dana ini akan digunakan untuk keperluan kegiatan yang berkaitan dengan promosi ASI eksklusif, misalnya sebagai uang pengganti transportasi kader.

\section{Sarana Prasarana}

Ketersediaan sarana dan prasarana untuk melakukan promosi pemberian ASI Eksklusif di Wilayah Kerja Puskesmas Pati II sudah cukup. Hal ini sesuai yang diungkapkan oleh informan utama sebagai berikut:

“...sarana prasarana sementara sudah cukup, sudah bisa jalan. Ada ruang laktasi di sini tapi sementara masih dalam perbaikan." (IU.1)

"Sarana prasarana promosi ASI eksklusif biasanya kerjasama dengan gizi, kalau di kelas ibu hamil menggunakan phantom bayi dan gambar payudara, poster lalu ada juga leaflet." (IU.2 dan IU.3)

Hal tersebut juga didukung oleh pernyataan informan triangulasi sebagai berikut:

“... mewajibkan tiap Puskesmas untuk mempunyai ruang laktasi, memberikan dropping konseling kit ke Puskesmas, memfasilitasi pembelian modul konseling $P M B A$, menyediakan leaflet dan poster dropping dari provinsi."(IT.1)

“...sarana media promosi poster maupun folder.” (IT.2)

Sarana dan prasarana di Puskesmas Pati II cukup memadai, hal ini sudah cukup menunjang dalam promosi pemberian ASI eksklusif. Ruang laktasi sudah tersedia tetapi sedang dalam proses perbaikan untuk memenuhi kriteria sesuai dengan Surat yang diterbitkan oleh Menteri Kesehatan No. 872/ MenKes/XI/2006 tentang Kriteria dan Fasilitas dari Ruang Laktasi. Promosi pemberian ASI eksklusif di Puskesmas Pati II yang dilakukan pada saat ibu hamil melakukan pemeriksaan hamil adalah dengan menggunakan buku KMS (Kartu Menuju Sehat) dan leaflet. Adapun di kelas ibu hamil dan kelas ibu balita menggunakan poster, phantom payudara, dan leaflet.

Media promosi kesehatan merupakan peralatan yang digunakan dalam penyampaian informasi kesehatan. Media promosi berguna untuk mempermudah penyampaian pesanpesan kesehatan bagi masyarakat. Media promosi kesehatan yaitu media cetak, elektronik, dan papan (Notoadmodjo, 2010). Berdasarkan hasil observasi, media promosi yang ada di Puskesmas Pati II adalah poster, spanduk, dan leaflet. Poster dan spanduk jumlahnya masih sedikit, ditempel di dinding Puskesmas. Sementara leaflet dibawa oleh tenaga-tenaga kesehatan. Kondisi poster, spanduk dan leaflet masih dalam keadaan bagus dan mudah dibaca.

Penelitian Lokra (2018), menyatakan bahwa media dan sarana merupakan alat yang efektif dalam membantu mempromosikan kesehatan. Ketersediaan media dan sarana promosi kesehatan yang memadai berpotensi mendukung tercapainya tujuan promosi kesehatan untuk menunjang terciptanya perubahan. Penambahan media yang sesuai dengan kebutuhan sangat diharapkan (Lokra, 2018). Sarana dan prasarana promosi kesehatan Puskesmas sesuai dengan acuan dalam standar sarana/prasarana promosi kesehatan Puskesmas, seperti: flipcharts dan stand, LCD projector, amplifier dan wireless microphone, kamera foto, megaphone/public address system, portable generator, tapel casset recorder/player, dan papan informasi. Sarana dan peralatan yang sebaiknya ada antara lain: screen, televisi, antena, VCD/ DVD player, komputer, printer, gadget kelengkapan laptop, dan kendaraan roda dua untuk penyuluhan (Kementerian Kesehatan RI, 2006).

\section{Standar Operasional Prosedur (SOP)}

Kebijakan yang ditetapkan di suatu wilayah akan dapat mempengaruhi keberhasilan program. Kebijakan tentang ASI eksklusif yang ada di wilayah kerja Puskesmas Pati II adalah PERBUP No. 54 Tahun 2012 tentang ASI eksklusif. Hal tersebut sesuai dengan yang diungkapkan oleh informan triangulasi sebagai berikut:

"Kebijakan DKK yaitu promosi edukasil sosialisasi dari petugas kesehatan ke masyarakat, IMD di tiap Puskesmas, kelas ibu hamil dan kelas ibu balita, tiap puskesmas wajib punya ruang laktasi, dan usulan materi PERBUP ASI Eksklusif No. 54 Tahun 2012." (IT.1) 
“... pendataan PHBS tiap desa melalui puskesmas, refreshing kader kesehatan desa di puskesmas tiap 2 bulan sekali, dan tidak diperbolehkan iklan susu formula di sarana pelayanan kesehatan." (IT.2)

SOP atau protap untuk promosi pemberian ASI eksklusif di Wilayah Kerja Puskesmas Pati II belum tersedia. Hal ini sesuai yang diungkapkan oleh informan utama sebagai berikut:

“...adanya SOP promosi kesehatan secara umum, penyuluhan di dalam gedung dan penyuluhan di luar gedung. " (IU.1)

"SOP ASI eksklusif yang khusus tidak ada karena biasanya include saat pemeriksaan kehamilan atau pas ada kelas ibu hamil." (IU.3)

Hal tersebut juga didukung oleh pernyataan informan triangulasi sebagai berikut:

“...PERBUP No. 54 Tahun 2012 sesuai dengan PP No. 33 Tahun 2012 tentang Pemberian ASI Eksklusif." (IT.1)

"Pedoman yang dipakai yaitu Peraturan Bupati No. 54 Tahun 2012.”(IT.2)

Promosi pemberian ASI eksklusif di Puskesmas II dilakukan dengan menyesuaikan SOP penyuluhan di luar gedung karena tidak ada SOP khusus tentang promosi pemberian ASI eksklusif. Meskipun tidak ada SOP khusus untuk promosi pemberian ASI eksklusif, namun promosi ASI eksklusif tetap dilakukan oleh bidan Puskesmas, bidan desa, petugas gizi, dan promotor kesehatan. Kondisi tidak adanya SOP promosi ASI eksklusif tidak membuat program promosi ASI eksklusif tidak berjalan, namun alangkah baiknya jika memang tersedia SOP promosi ASI eksklusif.

Tersedianya SOP memperlancar tugas bidan dan promotor kesehatan, sebagai dasar hukum bila terjadi penyimpangan, mengetahui dengan jelas hambatan-hambatannya dan mudah dilacak, mengarahkan bidan untuk disiplin dalam bekerja, sebagai pedoman dalam melaksanakan pekerjaan rutin (Asfian, 2008). Hal ini sejalan dengan hasil penelitian Yandrizal (2017) yang menjelaskan bahwa faktor yang menyebabkan kegagalan pemberian ASI eksklusif adalah kurang jelasnya peraturan pemerintah tentang pemberian ASI eksklusif (Suryani, et al., 2017).

Pedoman dalam melakukan upaya promosi pemberian ASI eksklusif di wilayah kerja Puskesmas Pati II adalah PERBUP No. 54 Tahun 2012 sesuai dengan Peraturan Pemerintah No. 33 Tahun 2012 pasal tentang pemberian ASI eksklusif. Ketidaktersediaan SOP promosi ASI eksklusif diharapkan menjadi perhatian dari Pemerintah Daerah Kabupaten Pati dalam rangka mewujudkan keberhasilan program ASI eksklusif. Ketersedian SOP promosi ASI eksklusif diharapkan mampu dilaksanakan secara tepat oleh petugas kesehatan yang berwewenang memberikan promosi.

Menurut Briawan (2004), upaya promosi pemberian ASI yaitu dengan membuat regulasi setingkat Peraturan Pemerintah (PP) untuk mengatur promosi susu formula bayi di media massa baik cetak maupun elektronik untuk menertibkan pemasaran susu formula. Setelah adanya perbaikan peraturan perundangan tersebut kemudian ditindaklanjuti dengan penegakan hukum.

\section{KESIMPULAN DAN SARAN}

\section{Kesimpulan}

Aspek input upaya promosi pemberian ASI eksklusif di wilayah kerja Puskesmas Pati II didukung oleh sumber daya manusia yang melakukan promosi ASI eksklusif adalah bidan, sumber dana promosi ASI eksklusif dari pemerintah yaitu dana BOK, ketersediaan sarana prasarana promosi ASI eksklusif sudah memadai, dan belum tersedianya SOP promosi pemberian ASI eksklusif.

\section{Saran}

Dinas Kesehatan perlu membuat SOP yang jelas untuk promosi pemberian ASI eksklusif bagi petugas promosi untuk mendukung promosi pemberian ASI eksklusif. Keberadaan SOP diharapkan pelaksanaan kegiatan promosi dapat dilaksanakan dengan baik, tanpa melalui kegiatan pelayanan kesehatan yang lain misal melalui kelas ibu hamil dan kelas ibu balita. 
Puskesmas perlu melakukan upaya perekrutan tenaga khusus promosi kesehatan sebagai SDM utama pelaksana kegiatan promosi kesehatan di Puskesmas. Puskesmas hendaknya melakukan pembinaan terhadap bidan desa dan kader kesehatan agar tetap aktif untuk meningkatkan cakupan ASI eksklusif dengan mengoptimalkan supervisi, monitoring dan evaluasi terhadap pencapaian cakupan ASI eksklusif.

Bidan hendaknya terus meningkatkan kualitas dan kuantitas kegiatan promosi pemberian ASI eksklusif dengan cara aktif meningkatkan peran serta masyarakat khususnya kader kesehatan dalam penjaringan ASI eksklusif, sehingga dapat meningkatkan cakupan ASI eksklusif.

Sebaiknya ibu hamil mengikuti kegiatankegiatan yang dijalankan oleh bidan desa, misalnya kelas ibu hamil dan kelas ibu balita. Kegiatan tersebut dapat meningkatkan pengetahuan ibu tentang ASI eksklusif, sehingga para ibu dapat memberikan ASI kepada bayi secara tepat dan mampu mengambil langkah yang sesuai apabila terjadi masalah dalam pemberian ASI.

\section{DAFTAR PUSTAKA}

Alimoradi, F., Maryam, J., Ameneh, B., Naser, K., Mohamad, A. (2014). An Overview of Importance of Breastfeeding. Jurnal Administrasi \& Kebijakan Kesehatan Indonesia, 2 (2), 19-28.

Aprilia. (2010). Analisis Sosialisasi Program Inisiasi Menyusu Dini dan ASI Eksklusif kepada Bidan di Kabupaten Klaten. Tesis. Semarang: Prodi Magister Ilmu Kesehatan Masyarakat Universitas Diponegoro.

Asfian. (2008). Analisis Pemanfaatan Pedoman Kerja Bidan dalam Pengelolaan Program KIA-KB di Puskesmas Kota Pontianak. Tesis. Semarang: Universitas Diponegoro.

Badan Pusat Statistik Kabupaten Pati. (2017). Sosial dan Kependudukan: Kesehatan. https://patikab.bps.go.id/subject/30/ kesehatan.html\#subjekViewTab1. Diakses tanggal 18 April 2018.
Briawan, D. (2004). Pengaruh Promosi Susu Formula terhadap Pergeseran Penggunaan Air Susu Ibu (ASI): Pengantar Falsafah Sains (PPS 702). Bogor: IPB.

Clark, S. G. J., Bungun, T. J. (2010). The Benefits of Breastfeeding: An Introduction for Health Educators. California Journal of Health Promotion, 1 (3), 158-163.

Departemen Kesehatan RI. (2007). Modul Dasar Penyuluh Kesehatan Masyarakat Ahli. Jakarta: Departemen Kesehatan.

Dinas Kesehatan Kabupaten Pati. (2016). Profil Kesehatan Kabupaten Pati 2015. Jakarta: Kementerian Kesehatan. http:// www.dinkes.patikab.go.id/wp-content/ uploads/2017/09/Profil-2016.pdf Diakses tanggal 18 April 2018.

Dinas Kesehatan Kabupaten Pati. (2017). Profil Kesehatan Kabupaten Pati 2016. Jakarta: Kementrian Kesehatan.

Dinas Kesehatan Propinsi Jawa Tengah. (2018). Profil Kesehatan Propinsi Jawa Tengah 2017. Jakarta: Kementerian Kesehatan.

Ernawati, A. (2014). Pengetahuan, Komitmen, dan Dukungan Sosial dalam Pemberian ASI Eksklusif pada Pegawai Negeri Sipil. Jurnal Litbang: Media Informasi Penelitian, Pengembangan dan IPTEK, $\mathrm{X}(1), 64-73$.

Ernawati, A. (2014). Peranan Sarana Pelayanan Kesehatan dalam Pemberian ASI Eksklusif: Studi pada Pegawai Negeri Sipil di Kecamatan Pati. Jurnal Litbang: Media Informasi Penelitian, Pengembangan dan IPTEK, X (2), 133-142.

Fikawati, S., Syafiq, A. (2009). Penyebab Keberhasilan dan Kegagalan Praktik Pemberian ASI Eksklusif. Kemas: Jurnal Kesehatan Masyarakat Nasional, 4 (3), 120-131.

Gibson. 2009. Organisasi Perilaku Struktur dan Proses. Jakarta: Binarupa Aksara.

Hartono, B. (2010). Promosi Kesehatan di Puskesmas dan Rumah Sakit. Jakarta: Rineka Cipta. 
Hasanah, Suhat. (2014). Faktor-faktor yang Berhubungan dengan Keaktifan Kader dalam Kegiatan Posyandu (Studi di Puskesmas Palasari Kabupaten Subang). KEMAS 10 (1), 73-79.

Keputusan Menteri Kesehatan Republik Indonesia No. 900/MenKes/SK/VII/2002 tentang Registrasi dan Praktik Bidan. 25 Juli 2002. Jakarta.

Keputusan Menteri Kesehatan RI No. 872/ MENKES/SK/XI/2006 Tentang Kriteria dan Fasilitas dari Ruang Laktasi. Kementerian Kesehatan RI. Jakarta.

Lingga, J. (2016). Implementasi Pencatatan Register Kohort Pelayanan Kesehatan Ibu dan Anak (KIA) oleh Bidan di Pus kesmas Nanga Pinoh. Wawasan Kesehatan, 2 (2), 76-93.

Lokra, C. T. (2018). Gambaran Program Promosi Kesehatan di Puskesmas Wenang Kecamatan Wenang Kota Manado. Jurnal IKMAS, 3 (1), 32-46.

Marmi. (2014). Asuhan Kebidanan Pada Masa Nifas "Peurperium". Yogyakarta: Pustaka Pelajar.

Mugeni, Sugiharto, Widjiartini. (2012). Analisa Pencapaian Target Program Promosi Kesehatan Menurut Jenis Puskesmas di Kabupaten Tulungagung. Indonesian Scientific Journal, 15 (4), 369-380.

Notoatmodjo, S. (2010). Kesehatan Masyarakat Ilmu dan Seni. Jakarta: Rineka Cipta.

Notoatmodjo, S. (2007). Promosi Kesehatan dan Ilmu Perilaku. Jakarta : Rineka Cipta.

Peraturan Menteri Kesehatan Republik No. 75 Tahun 2014 tentang Puskesmas. Kementerian Kesehatan RI. Jakarta.

Peraturan Menteri Kesehatan Republik Indonesia Nomor 971/Menkes/Per/XI/2009 tentang Standar Kompetensi Pejabat Struktural Kesehatan Menteri Kesehatan Republik Indonesia. 5 November 2009. Kementerian Kesehatan RI. Jakarta.

Prasetyono, D. S. (2012). Buku Pintar ASI Eksklusif. Yogyakarta : Diva Press.
Raharjo, B. B. (2014). Profil Ibu dan Peran Bidan dalam Praktik Inisiasi Menyusu Dini dan ASI Eksklusif. KEMAS, 10 (1), $53-63$.

Rahmawati, M. D. (2010). Faktor-Faktor yang Mempengaruhi Pemberian ASI Eksklusif Pada Ibu Menyusui di Kelurahan Pedalangan Kecamatan Banyumanik Kota Semarang. Jurnal Kesehatan Kusuma Husada, 1 (1), 8-17.

Rosita, N. A. (2016). Peran Dukungan Orang Tua Faktor yang Paling Berpengaruh terhadap Pemberian ASI Eksklusif. Unnes Journal of Public Health, 5 (4), 355365.

Santi, M. Y. (2017). Upaya Peningkatan Cakupan ASI Eksklusif dan Inisiasi Menyusui Dini (IMD). Jurnal Kemas Indonesia, 9 (1), 78-90.

Sari I., Sulistyowati, M. (2015). Analisis Promosi Kesehatan di Puskesmas Kalijudan terhadap PHBS Rumah Tangga Ibu Hamil. Jurnal Promkes, (3) 2, 159.

Sistiarani, C., Nurhayati S., Suratman. (2013). Faktor-Faktor yang Mempengaruhi Peran Kader dalam Penggunaan Buku Kesehatan Ibu dan Anak. Jurnal Kesehatan Masyarakat, 8 (2), 77-84.

Suryani, D., Simbolon, D., Elly, N., Pratiwi, B. A., Yandrizal. (2017). Deterninants Failure of Exclusive Breast Feeding on Health in the City Bangkulu. Jurnal Kesehatan Masyarakat, 12 (2), 96-104.

Suryani. (2009). Faktor-Faktor yang Mempengaruhi Pelaksanaan Program Promosi Kesehatan di Rumah Tangga yang Sehat di Wilayah Kerja Puskesmas Teladan Medan Kecamatan Medan Kota Tahun 2009. Tesis. Medan: Universitas Sumatera Utara.

Undang-Undang Republik Indonesia Nomor 36 Tahun 2014 tentang Tenaga Kesehatan.

Walyani, E. S., Purwoastuti, E. (2015). Asuhan Kebidanan Masa Nifas dan Menyusui. Yogyakarta: Pustaka Baru Press. 
Wibowo. M. (2016). Dukungan Informasi Bagi Ibu Menyusui Dalam Memberikan ASI Eksklusif di Kecamatan Gondokusuman, Yogyakarta. KEMAS, 11 (2), 96-103.

Wulandari, S. R., Handayani, S. (2011). Asuhan Kebidanan Ibu Masa Nifas. Yogyakarta : Nuha Medika.

Yunita, H., Kuntjoro, T., Purnami, C. T. (2013). Faktor-faktor yang Mempengaruhi Kinerja Bidan Desa dalam Deteksi Dini Resiko Tinggi Ibu Hamil pada Pelayanan Antenatal di Kabupaten Bengkulu Selatan. Jurnal Manajemen Kesehatan Indonesia, 01 (02), $79-88$

\section{BIODATA PENULIS}

Tri Ari Prasetyowati, lahir pada tanggal 29 Januari 1985 di Kabupaten Pati. Sarjana Sains Terapan dari Poltekkes Surakarta. Saat ini sedang menempuh pendidikan parcasarjana jurusan Ilmu Kesehatan Masyarakat di Universitas Negeri Semarang. Bekerja di Akademi Kebidanan Duta Dharma Pati sebagai Dosen.
Ari Yuniastuti, lahir pada tanggal 2 Juni 1968 di Semarang. Doktor dalam bidang Ilmu Kedokteran dari Universitas Hasanudin Sulawesi Selatan. Bekerja di Universitas Negeri Semarang sebagai Dosen.

Oktia Woro Kasmini Handayani, lahir pada tanggal 1 Oktober 1959 di Yogyakarta. Doktor dalam bidang Studi Pembangunan dari Universitas Kristen Satya Wacana Salatiga. Bekerja di Universitas Negeri Semarang sebagai Dosen. 
